\title{
Byron David Halsted and Experiment Station Plant Pathology 1889 to 1900
}

\author{
Clay S. Griffith, Research Assistant, Paul D. Peterson, Jr., Project Historian, and C. Lee Campbell, Professor, \\ Department of Plant Pathology, North Carolina State University, Raleigh 27695-7616
}

In the final decade of the nineteenth century, plant pathology in America underwent rapid growth and significant transformation, reflecting changing conditions in science and agriculture as well as in the institutions that supported these endeavors. Among the most important institutions for the development of plant pathology were the state agricultural experiment stations. The view of experiment station scientists was primarily local in its focus; station scientists were dedicated to studying and alleviating the agricultural problems in their own state or region. Each station botanist was, however, still a part of the growing network of professional scientists interested in plant pathology, conversant in the same principles and practices, and moved by the same problems inherent to American science and agriculture.

Perhaps the quintessential example of an experiment station botanist came from New Jersey. From 1889, under the guidance of the energetic and intelligent botanist Byron David Halsted (Fig. 1), the New Jersey State Agricultural Experiment Station at Rutgers College quickly became an essential part of the state's agricultural life. Wanting to be neither an agricultural technician who only sprayed fungicides nor a closet scientist who never left the microscope, Halsted walked the tightrope between practical service and fundamental science with unusual ease and skill. He wrote and vigorously disseminated numerous, useful publications on plant diseases and their control to the growers and gardeners of New Jersey while contributing a wealth of knowledge about pathogens and diseases to the corpus of plant pathology. Byron Halsted worked at a time when applied plant pathology was becoming more vital to America's expanding agricultural production.

During the second half of the nineteenth century, as the United States expanded and transformed itself into an industrial nation, American agriculture changed rapidly.

Corresponding author: Paul D. Peterson, Jr. E-mail: paul_peterson@ncsu.edu

Accepted for publication 27 January 1997.

Publication no. D-1997-0306-06S

(C) 1997 The American Phytopathological Society
Regional specialization became even more pronounced as the country focused on crops that could be grown in quantity for a market that continued to expand in size and in distance from field to consumer. A transportation boom, particularly in railroads, and a movement toward farm mechanization helped foster these trends (19). Agriculture was perceived as an enterprise essential for national prosperity, and an increasingly activist federal government played a role in ensuring the wellbeing of this enterprise through the establishment of the United States Department of Agriculture (USDA) and a national system of land-grant colleges (3).

As these agricultural institutions became established, numerous scientists, agriculturists, and politicians held the conviction that farming could be improved through the application of science. They believed that many agricultural problems, including those posed by the diseases of plants and animals, could be solved only by the application of principles from biology and chemistry. Therefore, they not only pushed for more scientific research in the USDA and the land-grant colleges, but also supported the establishment of state agricultural experiment stations as another site for applying science to the betterment of agriculture.

The first state agricultural experiment station was established in Connecticut in 1875 , followed by a handful in other states over the next decade $(6,20,25)$. However, the scientific dreams of the early organizers of these stations went largely unrealized. Funding for stations by state legislatures or private donations was haphazard. Controversy continued over whether agricultural scientists should focus on immediate, practical service or on fundamental research, which would serve farmers in the longer term. Station scientists, most often chemists, spent much of their time analyzing the composition of commercial fertilizers. Those with botanical training often found their time occupied with parochial requests to identify weeds and examine seeds for purity $(1,24)$. Few opportunities existed at experiment stations for mycologists or botanists who wanted to study plant diseases.

There were a few examples of workers at state agricultural experiment stations directing their attention to plant diseases.
Perhaps the most notable was at the New York station in Geneva, where Joseph Charles Arthur did important research on the bacterial nature of fire blight of pome fruit, confirming the earlier, ground breaking work of Thomas J. Burrill of Illinois. In addition, Arthur and another station worker, Emmett Stull Goff, investigated a variety of disease problems in the mid-1880s, performing excellent etiological research with a general focus on diseases of tree fruit and garden crops of western New York (5). They could make only limited contributions to disease control, at best restating cultural and sanitation practices, because no arsenal of practical chemical remedies was available at the time.

A new era of applied plant pathology was, however, about to commence. Frank Lamson-Scribner faced the same dilemma as station scientists when he became head of the USDA's newly created Section of Mycology in 1886. His clearly defined mission was to understand plant diseases caused by fungi, with the ultimate goal of

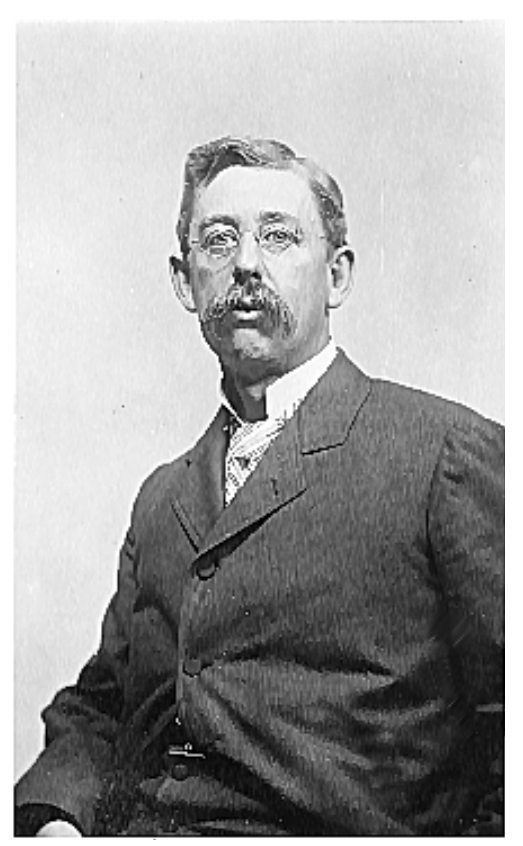

Fig. 1. Byron David Halsted. Courtesy Special Collections and University Archives, Rutgers University Libraries. 
developing cures and controls for these diseases. This mandate for practical disease control methods was one of the central differences between the plant disease research that Scribner embarked on and that which had come before. For example, William G. Farlow, the noted nineteenth century Harvard mycologist who took an interest in economic botany, rarely felt intense pressure to produce information that would lead directly to effective control measures for plant diseases. Scribner's obligation to aid farmers, however, moved him to combine fungal life-history work done in the laboratory with field-tested disease control strategies to forge a science that would be obviously useful and of clear practical benefit to agriculture. His most lasting legacy to this new applied science of plant pathology was the widespread use of fungicides. With the federal government as the chief advocate and sponsor, applied plant pathology grew rapidly after the successes scored by Scribner and his successor, Beverly T. Galloway, in the late 1880 s (22).

The advocates of agricultural science recognized a void in attention to local and regional agricultural problems, including plant diseases, that simply could not be provided effectively from Washington. These advocates pushed for a more extensive system of research institutions; and in 1887, Congress passed the Hatch Act, creating a network of federally funded state agricultural experiment stations. Under the Hatch Act, the number of experiment stations across the United States nearly tripled. Prior to the passage of the Act, there were 17 in 14 states. One year later, there were 46 experiment stations, 43 of which were funded by Hatch Act appropriations $(20,29)$. The stage was thus set for a rapid expansion of attention to plant diseases across the United States.

Byron D. Halsted would become one of the most important scientists to take up the study of plant diseases in the first decades of federally funded agricultural experiment stations. Halsted, born in June 1852 in Venice, New York, was orphaned at an early age and raised by relatives. $\mathrm{He}$ earned both bachelors (1871) and masters (1874) degrees from the Michigan Agricultural College and then went to Harvard as the first doctoral student of William Farlow. Halsted, with a dissertation entitled "Classification and Description of the American Species of Characeae," was the first person to receive a doctorate in cryptogamic botany at an American university (1878) (28,30). After college, he spent several years as the editor of the widely read journal American Agriculturist, allowing him to become acquainted with the leaders of American botany and to acquire the skills and motivation to write insightful and useful bulletins on plant disease problems (4). It was Halsted who reportedly coined the term "fungicide" in a paper delivered before the American Pomological Society in $1883(7,14)$. In 1885 , he was named professor of botany at the Iowa Agricultural College, where he taught for 4 years. During his time in Ames, he increasingly became interested in economic botany and plant diseases caused by fungi, and he wrote two bulletins on the subject, each covering more than 40 diseases (21). In 1889, Halsted left Iowa for Rutgers College in New Brunswick, New Jersey, where on the recommendation of Farlow, he was named professor of botany and horticulture as well as staff botanist of the experiment station $(4,23)$.

Overall, Halsted's research agenda was determined largely by regional economics and dominated by practicality. Truck farming had become prominent in New Jersey by the 1890 s. This meant that Halsted devoted much of his time to the study of the diseases of many vegetables, fruits, and ornamentals that were important to that developing industry, many of which had received little if any previous systematic treatment. Every year, Halsted wrote bulletins and reports about numerous diseases, although sometimes he merely mentioned their existence and explained what was known about them based on the existing literature. Few pertinent diseases of garden, orchard, or nursery escaped his scrutiny on some level. One of his biographers noted in 1919 that "our younger plant pathologists know how difficult it is to find a disease of an economic crop that is not at least mentioned in his reports" (2). However, Halsted also contributed massive amounts of new information about some diseases, with detailed discussions of fungal life histories and disease cycles. Halsted's nephew, the noted plant pathologist and plant explorer David G. Fairchild, observed that "there always seemed to me to be a characteristic disorder about my uncle's laboratory. It was different from the general run of experiment station laboratories.... There were so many interesting problems going on" (4). Fortunately, the rigors of such a broad-based and demanding program generally agreed with Halsted. He seemed comfortable, at most times, simultaneously juggling the numerous tasks of a station botanist: visiting growers' fields, diagnosing diseases, searching for causes of diseases, testing new chemicals for disease control, speaking at growers' meetings, writing bulletins, reading the literature, and corresponding regularly with plant disease workers in other states and at the USDA in Washington, DC.

Much of Halsted's regionally based research was modeled on the applied plant pathology efforts of the USDA. The approach to solving a disease problem was to determine the causal agent, if it was unknown, and then attempt to unravel its life history to better facilitate the potential usefulness of chemical sprays. Tests with various chemical compounds were carried out, and the most promising were evaluated during subsequent growing seasons. This process was a centerpiece of experiment station plant pathology around the country as chemical applications became an accepted and integral part of American agriculture in the 1890s. This research sometimes served primarily to confirm control practices for locally troublesome diseases that had already been demonstrated successfully by USDA scientists or at experiment stations in other regions of the country. Part of the service also included disseminating useful information on buying or mixing fungicides as well as on selecting sprayers and nozzles. Although results obtained in each state may not have been wholly original, this was an effective method for solving disease problems on a state-by-state basis, and it fit well into the experiment station's mandate to provide practical assistance for agriculturists.

Halsted conducted or supervised spraying trials every year on a wide range of diseases such as clubroot of cabbage and turnip, leaf blight of tomato, potato scab, and bean anthracnose, as well as many tree fruit and grape diseases $(15,27)$. In his first several years at Rutgers, he carried out his tests at fields and orchards around New Jersey, but "the inability to watch closely the work has rendered the results somewhat unsatisfactory" (15). In 1894, the testing of fungicides commenced on five crops, "a group fairly representing the market-garden products of the State," on 1 acre at the College Farm (15). Five years later, the land had expanded by only one additional acre, but the number of crops had more than tripled, all under the close and watchful eye of Halsted or his field assistants. However, most of his fungicide tests for fruit tree diseases were still conducted off-campus in the orchards of cooperating growers around the state $(16,17)$. Halsted readily suggested, either in conjunction with chemicals or in lieu of them if tests failed, useful cultural practices such as crop rotation and selection of diseasefree seeds or seedlings. He also advocated sanitation procedures such as destroying sources of overwintering inoculum by clearing postharvest plant debris from infested fields and pruning diseased tree limbs, and he cautioned farmers against allowing livestock to wander from field to field, potentially spreading disease-causing organisms.

In addition to designing and carrying out experiments, Halsted had a talent for communicating practical disease control information in clear, concise bulletins that contributed considerably to the public perception of the experiment station's value. Halsted believed that "to publish much technical science in the general bulletin both burdens the farmer and the man of science. The strictly scientific matters, as descriptions of new species etc., that have no practical bearing to the farmer, had best 
be published in journals designed for such purposes" (10). And while Halsted certainly wrote a number of excellent, strictly scientific papers, the majority of his experiment station bulletins reflected his practical, plain-spoken nature.

Because of regional agricultural needs, one of the areas of practical research that attracted Halsted was the study of postharvest diseases. He was one of the first to delve into this area, prompted by the increasing distance that fruits and vegetables were transported to markets. Diseases of sweet potato, particularly black rot, caused by Ceratocystis fimbriata (Fig. 2), and soft rot, caused by Rhizopus nigricans, were major impediments to the effective storage and transit of this produce. In any given year, black rot alone threatened to destroy as much as $30 \%$ of the sweet potato crop along the mid-Atlantic seaboard. Halsted worked with Fairchild, then an assistant in the Division of Vegetable Pathology in Washington, DC, to isolate the causal agent of black rot in pure culture and inoculate healthy sweet potatoes, thus confirming a fungal cause for the disease. Soft rot could be controlled effectively by proper storage, but little could be offered to control black rot at this time aside from the advice to use only "healthy sets" and practice crop rotation $(9,18)$.

Another destructive disease that drew a significant amount of Halsted's attention was clubroot of cabbage (Fig. 3). First described scientifically in 1877 in the pioneering work by Michael Stepanovitch Woronin in Russia, clubroot, caused by Plasmodiophora brassicae, had a long and destructive history among crucifers such as cabbage and turnips (31). Clubroot could be quite serious, as Halsted noted, "sometimes incurring almost a total loss, and in the aggregate the destruction for the whole country is doubtless represented by millions of dollars." The disease concerned Halsted because it "prevailed extensively in the truck regions around the large cities of New York and Philadelphia" (13). In 1893, he summarized Woronin's work on the organism, and he added information about weeds susceptible to clubroot that served as reservoirs for the disease and should be destroyed to prevent the spread of the pathogen. He explained that because the pathogen attacked belowground, this foiled hopes of chemically treating the plant. Halsted reiterated the traditional preventative cultural measures provided by Woronin in 1878: crop rotation, burning all refuse from diseased plants, and choosing disease-free seedlings from hotbeds. However, Halsted also recommended liming the soil as a means of disease control. Lime had shown promising results in truck farming regions near New York and, although its successful use still needed experimental confirmation, Halsted was willing to tentatively endorse the practice that Woronin had dismissed.
In another example of his wide-ranging plant disease attention, Halsted's work on cranberry diseases demonstrated not only another aspect of his varied agenda, but also the growing role that experiment station scientists could play in determining agricultural policy. Nearly one-third of New Jersey's crop was destroyed routinely by two diseases: gall, caused by Synchytrium vaccinii, and scald, caused by Guignardia vaccinii. In 1889, Halsted outlined the life histories of these two fungi in a special bulletin (8). The next year, field experiments in cranberry bogs around the state proved that fungicides were ineffective. Halsted, in his role as resident expert and communicator of disease information, addressed the American Cranberry Growers' Association in 1889, and influential members of the Association took his presentation to heart and demanded government action. In 1890, the New Jersey legislature responded and passed "An Act to prevent the spread of fungous diseases of plants" stating "that when the officers of the State Agricultural Experiment Station shall discover any new fungous growth which is doing injury to plants or vines, and while the same is confined to limited areas, they are hereby authorized and empowered to enter upon any lands bearing vines or plants so affected, and destroy the same by fire or otherwise, as they shall deem best" (11). In addition to destroying cranberries to interrupt the spread of the

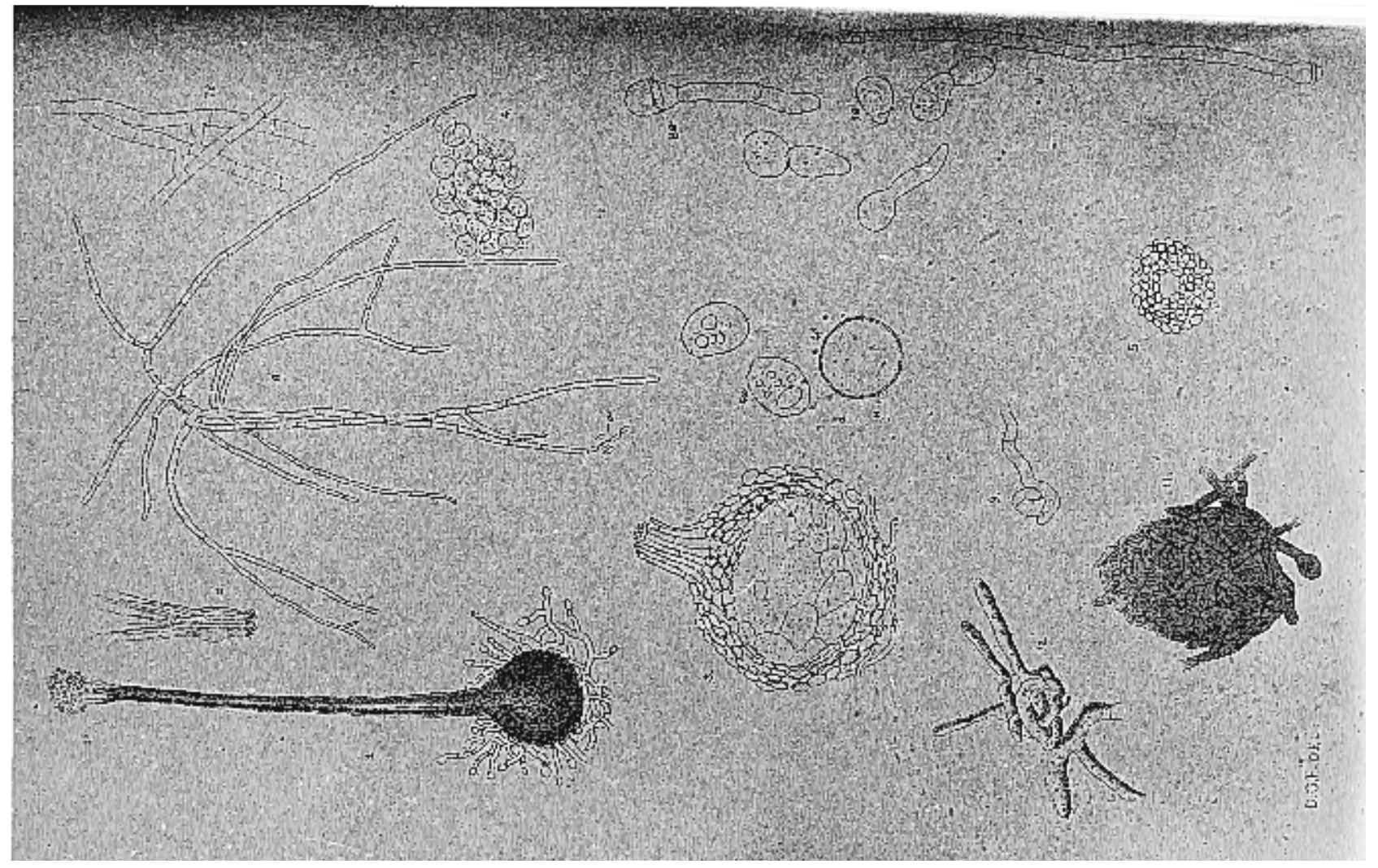

Fig. 2. Sweet Potato Black Rot Fungi. These illustrations are from B. D. Halsted and D. G. Fairchild (18). 
pathogen, Halsted determined that improved water management in the bogs was the best method of disease prevention. The success of Halsted's investigations was instrumental in reinvigorating the cranberry industry in New Jersey (30).

On occasion, the volume of work that faced Halsted was extremely challenging. $\mathrm{He}$ was the sole experiment station botanist, and he had to handle any problem that came his way to the best of his ability with limited assistance. Halsted found himself confronted with so many crops and diseases that he could not always carry out experiments with what he believed to be the proper thoroughness and proficiency. A particularly telling example of Halsted being stretched outside his realm of expertise came in 1892 when Samuel M. Tracy, director of the Mississippi Experiment Station, desperately wanted a capable scientist to study a blight of tomatoes that was causing alarm among growers in the South. He sought advice from the USDA, confirming, in essence, that Beverly Galloway, chief of the Section of Vegetable Pathology, was positioning the USDA to coordinate the study of plant diseases in the United States as part of a centralized agricultural policy. After considering several scientists, Galloway recommended Halsted to Tracy.

True to his reputation as a fast worker with an interest in systematizing widespread information on diseases, Halsted spent only a couple of weeks in the field in Mississippi and returned to his laboratory in New Jersey. Based on microscopic observation of diseased plants, he made several important and lasting discoveries about the disease and the pathogen. He theorized that southern blight was caused by a bacterium, Bacterium solanacearum, now known as Pseudomonas solanacearum. In addition, after cross-inoculations, he astutely linked the tomato disease with a similar condition in potatoes, popularly known in some areas of the country as "brown rot."

In his published bulletin on "Southern Tomato Blight," however, Halsted freely admitted that his results were "subject to modification in the light of further results from field observations and laboratory experiments" (12). He did not make pure cultures of the bacterium, leaving that for the future or, as it turned out, for other scientists. Without the benefit of pure culture techniques, he made an incorrect connection between the southern blight and another similar disease. Spurred by farm-

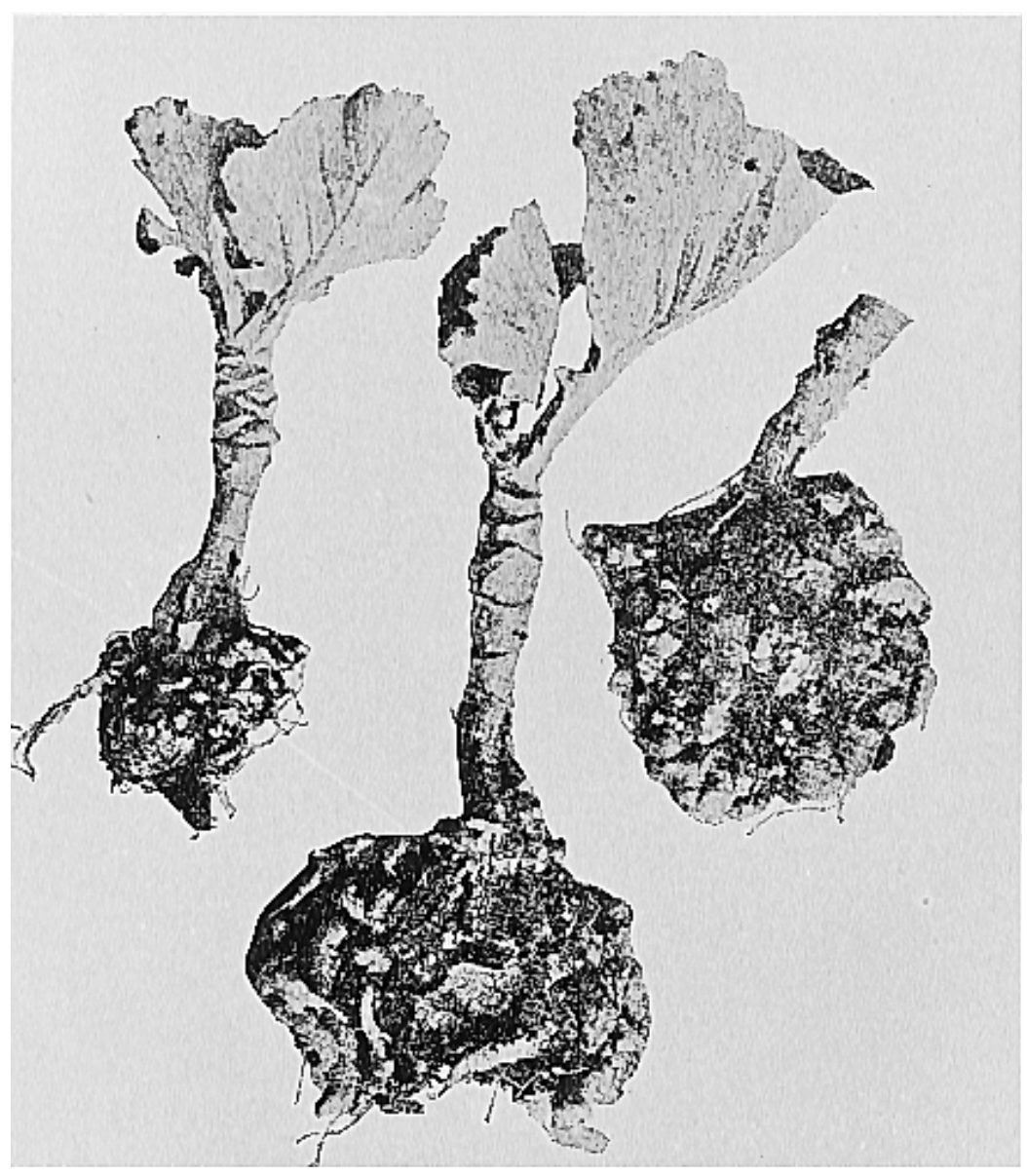

Fig. 3. Club Root of Cabbage. From B. D. Halsted (13).

ers' complaints of a melon blight, Halsted inoculated melon plants with $B$. solanacearum and observed the same wilting symptoms that had occurred in tomatoes and potatoes. Then, with trepidation, he noted that the "blight of melons and cucurbits... of bacterial origin" that was damaging crops along the north Atlantic seaboard "seems to be the same as the blight of the tomato and potato" (12). The symptomatology of the southern blight and the cucurbit wilt were indeed quite similar; however, Erwin Frink Smith, an accomplished and careful bacteriologist who reviewed Halsted's papers on the subject 4 years later, found that "two distinct diseases appear to be confused in these writings" (26). Smith, with more time and a laboratory better equipped to make a careful and thorough investigation of the disease, correctly identified the causal pathogen of the bacterial wilt of cucurbits as Bacillus tracheiphilus (now known as Erwinia tracheiphila).

The mistakes Halsted made were not unexpected due to the many new and diverse elements of plant pathology that were coming together in the late nineteenth century. It was an extremely difficult time for a generalist such as Halsted. He not only labored to document and understand diseases across a range of crop plants, but he also had to have a working knowledge or familiarity with the growing number of fungal pathogens, bacteria, nematodes, and the growing body of work on physiology and the environment. Additionally, Halsted felt compelled to keep up with the increasing sophistication of laboratory equipment and techniques. Although he may have exhibited predilections for particular disciplines, crops, or diseases, he really did not have the luxury of concentrating on any one of these areas. To fulfill his obligation as a station scientist, he had to remain a generalist and dedicate his energies to the increasing demands of his understaffed operation. David Fairchild wrote that "Dr. Halsted will be criticized for covering so wide a field of botany and for not specializing more narrowly, but this was not his nature, and when I try to compare him with men who have spent fifty years monographing a single family, I cannot do it.... A single correct observation may be quite as valuable as a life-long elaborated theory" (4).

By the turn of the century, Halsted was moving away from the study of plant diseases. His draining work load was having an effect. His eyesight began to fail to such an extent that it was difficult for him to use a microscope. So he switched his research emphasis to plant breeding and had a productive second career in that field. As in plant pathology, Halsted's breeding work was dominated by truck farming crops such as tomatoes, eggplant, peas and beans, and sweet corn. And, as in plant pathology, Halsted's program was a suc- 
cess. For the first decade, the program was essentially practical; he was interested in creating new varieties that could be put into the field as quickly as possible. But then in 1908, Halsted began taking the botany department in a fresh direction based upon the emerging science of genetics. Rather than creating new hybrids, he now wanted "to find out the methods by which a fruit like the tomato may be modified and place that information in the hands of the practical growers for their use upon their own grounds" (30). This was a reflection of the trend in the early twentieth century for extension workers to handle the practical aspects of agricultural sciences, which allowed experiment station scientists to focus more intently on fundamental research.

Byron Halsted died in August 1918. He left a legacy of over 300 bulletins and articles on plant pathology and plant breeding, as well as general and cryptogamic botany. Perhaps even more importantly, he played an integral part in establishing the state agricultural experiment station as a home for the science of plant pathology in the United States. He was a fine scientist with an agile mind. He had grappled with a wide range of problems with an energy and skill that eluded many of his colleagues who had concentrated on a more limited number of issues. He was also true to the applied side of plant pathology and plant breeding, mindful of communicating useful accounts and timely information to his primary constituents, the farmers of his state. His career exemplified the difficulty and the promise of the state agricultural experiment stations in the late nineteenth century.

By the turn of the century, the science of plant pathology was developing into a selfconscious discipline, establishing its own corpus of knowledge, its own group of practitioners who were certified through education and training, and a growing network of professional opportunities and associations, separating itself from its scientific progenitors such as botany, mycology, and bacteriology. Halsted was a leader in this movement. As one of the first Americans to hold a doctorate in cryptogamic botany, his attention to practical agricultural and economic problems demonstrated the need for dependable scientific contributions to the field of plant pathology. He also served to counter the attitude held by some scientists in traditional botanical disciplines that plant pathology was merely "squirt-gun botany." As a master communicator, he could address both the farmer and the scientist. He could write plain-spoken bulletins and technical journal articles and speak before yield-minded commodity associations and august bodies such as the American Association for the Advancement of Science. This was the tightrope walked by all of the state agricultural experiment stations, the dual constituency that challenged so many scientists. Halsted was among the best at traversing the chasm in the late nineteenth century.

\section{LITERATURE CITED}

1. Busch, L., and Lacy, W. B. 1983. Science, Agriculture and the Politics of Research. Westview Press, Boulder, CO.

2. Cook, M. T. 1919. Byron David Halsted. Bot. Gaz. 67:169-170

3. Dupree, A. H. 1957. Science in the Federal Government: A History of Policies and Activities to 1940. Harvard University, Cambridge, MA.

4. Fairchild, D. 1919. Byron David Halsted, botanist (1852-1918). Phytopathology 9:1-6.

5. Goff, E. S. 1890. Prevention of Apple Scab. Univ. Wis. Agric. Exp. Stn., Madison. Bull. 23.

6. Hadwiger, D. F. 1982. The Politics of Agricultural Research. University of Nebraska, Lincoln.

7. Halsted, B. D. 1884. The white mildews. Pages 87-89 in: Proc. Sess. Am. Pomol. Soc., 19th.

8. Halsted, B. D. 1889. Some Fungus Diseases of the Cranberry. N.J. Agric. Coll. Exp. Stn., New Brunswick. Bull. 64.

9. Halsted, B. D. 1890. Some Fungous Diseases of the Sweet Potato. N.J. Agric. Coll. Exp. Stn., New Brunswick. Bull. 76.

10. Halsted, B. D. 1890. Station botanists at Champaign. Bot. Gaz. 15:334-339.

11. Halsted, B. D. 1891. Report of the botanical department. Pages 323-370 in: Annu. Rep. N.J. State Agric. Exp. Stn., 11th, and Annu. Rep. N.J. Agric. Coll. Exp. Stn., 3rd, Year 1890. John L. Murphy Publishing, Trenton, NJ.

12. Halsted, B. D. 1892. The Southern Tomato Blight. Miss. Agric. Mech. Coll. Exp. Stn., Agric. Coll. Bull. 19.

13. Halsted, B. D. 1893. Club-Root of Cabbage and its Allies. N.J. Agric. Coll. Exp. Stn., New Brunswick. Bull. 98.

14. Halsted, B. D., to B. T. Galloway, April 5, 1893. General Letters Received, 1891-1900. Records of the Division of Vegetable Pathological and Physiological Investigations. Records of the Bureau of Plant Industry, Soils, and Agricultural Engineering. Record Group 54. National Archives II, Beltsville, MD.

15. Halsted, B. D. 1895. Field Experiments with
Fungicides. N.J. Agric. Coll. Exp. Stn., New Brunswick. Bull. 108

16. Halsted, B. D. 1898. Report of the botanist. Pages 263-394 in: Annu. Rep. N.J. State Agric. Exp. Stn., 18th, and Annu. Rep. N.J. Agric. Coll. Exp. Stn., 10th, Year Ending October 31st, 1897. J. L. Murphy Publishing, Trenton, NJ.

17. Halsted, B. D. 1900. Report of the botanist. Pages 323-419 in: Annu. Rep. N.J. State Agric. Exp. Stn., 20th, and Annu. Rep. N.J. Agric. Coll. Exp. Stn, 12th, Year Ending October 31st, 1899. Sinnickson Chew \& Co. Camden, NJ.

18. Halsted, B. D., and Fairchild, D. G. 1891. Sweet-potato black rot (Ceratocystis fimbriata, Ell. \& Hals.). J. Mycol. 7:1-11.

19. Hurt, R. D. 1994. American Agriculture: A Brief History. Iowa State University, Ames.

20. Knoblauch, H. C., Law, E. M., and Meyer, W. P. 1962. State Agricultural Experiment Stations: A History of Research Policy and Procedure. U.S. Dep. Agric. Misc. Pub. No. 904.

21. Pammel, L. H. 1919. In memorium. Dr. Byron D. Halsted. Proc. Iowa Acad. Sci. 26:31-33

22. Peterson, P. D., Jr., Griffith, C. S., and Campbell, C. L. 1996. Frank Lamson-Scribner and American plant pathology, 1885-1888. Agric. Hist. 70:33-56.

23. Rodgers, A. D. 1952. Erwin Frink Smith: A Story of North American Plant Pathology. Memoirs of the American Philosophical Society, vol. 31. American Philosophical Society, Philadelphia, PA.

24. Rosenberg, C. E. 1971. Science, technology, and economic growth: The case of the agricultural experiment station scientist, 18751914. Agric. Hist. 45:1-20.

25. Rossiter, M. W. 1975. The Emergence of Agricultural Science. Justus Liebig and the Americans, 1840-1880. Yale University, New Haven, CT.

26. Smith, E. F. 1896. A Bacterial Disease of the Tomato, Eggplant and Irish Potato (Bacillus solanacearum n. sp.). U.S. Dep. Agric. Div. Vege. Physiol. Pathol. Bull. 12.

27. Smith, J. B., and Halsted, B. D. 1892. Spraying for Insect and Fungous Pests of the Orchard and Vineyard. N.J. Agric. Coll. Exp. Stn., New Brunswick. Bull. 86.

28. Stevens, F. L., Pammel, L. H., and Cook, M. T. 1920. Byron David Halsted, June 7, $1852-$ August 28, 1918. Am. J. Bot. 7:305-317.

29. True, A. C. 1937. A History of Agricultural Experimentation and Research in the United States 1607-1925, Including a History of the United States Department of Agriculture. U.S Dep. Agric. Misc. Pub. No. 251

30. Woodward, C. R., and Waller, I. N. 1932 Botany: Byron David Halsted. Pages 251-269 in: New Jersey's Agricultural Experiment Station, 1880-1930. New Jersey Agricultural Experiment Station, New Brunswick.

31. Woronin, M. 1934. Plasmodiophora brassicae: The Cause of Cabbage Hernia. Phytopathological Classics No. 4. Charles Chupp, ed. American Phytopathological Society, Ithaca, NY. 